(2)

\title{
Tissue kallikrein deficiency, insulin resistance, and diabetes in mouse and man
}

\author{
Louis Potier $^{1,2,3,4,6}$, Ludovic Waeckel ${ }^{1,2,3}$, Fréderic Fumeron ${ }^{5,6}$, Sophie Bodin $^{1,2,3}$, \\ Marinos Fysekidis ${ }^{5,6}$, Catherine Chollet ${ }^{1,2,3}$, Naima Bellili, ${ }^{5,6}$, Fabrice Bonnet ${ }^{7}$, \\ Gaëlle Gusto $^{8}$, Gilberto Velho ${ }^{5,6}$, Michel Marre ${ }^{4,5,6}$, François Alhenc-Gelas ${ }^{1,2,3}$,

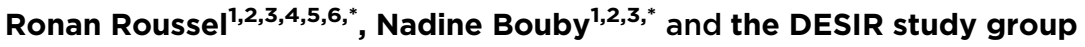 \\ ${ }^{1}$ INSERM U1138, Centre de Recherche des Cordeliers, 15 rue de l'Ecole de Médecine, 75006 Paris, France \\ ${ }^{2}$ University Paris Descartes, Paris, France \\ ${ }^{3}$ University Pierre and Marie Curie, Paris, France \\ ${ }^{4}$ Diabetology, Endocrinology and Nutrition Department, AP-HP, Bichat-Claude Bernard Hospital, Paris, France \\ 5 INSERM U695, Paris, France \\ ${ }^{6}$ Paris Diderot University, Paris 7, Paris, France \\ ${ }^{7}$ Department of Endocrinology, CHU Rennes, Univ Rennes 1, Inserm UMR 991, Rennes, France \\ ${ }^{8}$ Institut inter Régional Pour la Santé, Irsa, La Riche, France \\ *(R Roussel and $\mathrm{N}$ Bouby are equally senior co-authors of this paper)
}

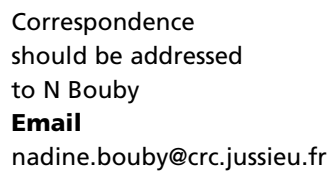

\begin{abstract}
The kallikrein-kinin system has been suggested to participate in the control of glucose metabolism. Its role and the role of angiotensin-l-converting enzyme, a major kinininactivating enzyme, are however the subject of debate. We have evaluated the consequence of deficiency in tissue kallikrein (TK), the main kinin-forming enzyme, on the development of insulin resistance and diabetes in mice and man. Mice with inactivation of the $T K$ gene were fed a high-fat diet (HFD) for 3 months, or crossed with obese, leptindeficient (ob/ob) mice to generate double ob/ob-TK-deficient mutants. In man, a loss-offunction polymorphism of the $T K$ gene $(R 53 H)$ was studied in a large general population cohort tested for insulin resistance, the DESIR study (4843 participants, 9 year follow-up). Mice deficient in TK gained less weight on the HFD than their WT littermates. Fasting glucose level was increased and responses to glucose (GTT) and insulin (ITT) tolerance tests were altered at 10 and 16 weeks on the HFD compared with standard on the diet, but TK deficiency had no influence on these parameters. Likewise, ob-TK ${ }^{-1-}$ mice had similar GTT and ITT responses to those of ob-TK ${ }^{+/+}$mice. TK deficiency had no effect on blood pressure in either model. In humans, changes over time in BMI, fasting plasma glucose, insulinemia, and blood pressure were not influenced by the defective $53 \mathrm{H}$-coding TK allele. The incidence of diabetes was not influenced by this allele. These data do not support a role for the TK-kinin system, protective or deleterious, in the development of insulin resistance and diabetes.
\end{abstract}

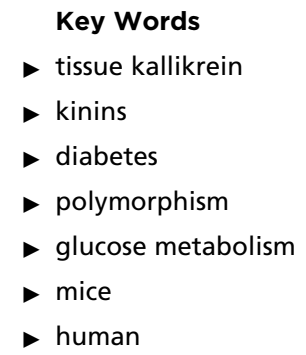

Journal of Endocrinology (2014) 221, 297-308

\section{Introduction}

The prevalence of obesity is increasing worldwide, together with the metabolic and cardiovascular complications of the condition, related in part to insulin resistance (Ogden et al. 2012). Intervention trials aimed at preventing 
obesity-related disorders have provided encouraging but still limited results (Satterfield et al. 2003, Laatikainen et al. 2007). The pathogenesis of insulin resistance and diabetes in obesity is complex and still incompletely understood. Besides nutritional and metabolic factors, hemodynamic alterations, and vascular dysfunction are believed to play a role (Mather et al. 2013). Vasomotor peptide systems, especially the renin-angiotensin and kallikrein-kinin systems (KKS), have been suggested to be involved in the development of insulin resistance (Mayfield et al. 1996, Sarzani et al. 2008), a hypothesis that has been recently supported by the results of clinical trials.

Clinical trials have indeed suggested that angiotensinconverting enzyme (ACE) inhibitors and several angiotensin II AT1 receptor antagonists improve insulin sensitivity and prevent type 2 diabetes in high-risk patients, albeit this effect has not been observed in all studies (Abuissa et al. 2005, Bosch et al. 2006). ACE (kininase II) converts angiotensin I into angiotensin II and is also a major kinin-degrading enzyme. There is consistent experimental evidence indicating that the cardiovascular and renal effects of ACE inhibitors, including in diabetes, are due in large part to kinins (Liu et al. 2000, Griol-Charhbili et al. 2005, Buleon et al. 2008). Similarly, angiotensin II AT1 receptor blockade induces renin secretion and AT2 receptor activation, which triggers tissue kallikrein (TK) or plasma kallikreinmediated kinin release and kinin receptor activation (Zhu et al. 2012). Cardiac, vascular, and renal effects of AT1 receptor blockers, like those of ACE inhibitors, are suppressed experimentally by pharmacological or genetic inactivation of TK, the main kinin-forming enzyme, or kinin receptors. Thus, a prominent role for TK and kinins in these effects is indicated (Bergaya et al. 2004, MessadiLaribi et al. 2007). The question therefore arises as to whether the KKS is involved in the beneficial effect on glucose metabolism of ACE inhibition and AT1 receptor blockade observed in clinical trials. This hypothesis is further supported by experimental studies documenting improvement mediated by kinins of insulin resistance during ACE inhibitor treatment in obese and diabetic rodent models (Henriksen et al. 1999, Shiuchi et al. 2002). TK gene therapy has been reported to reverse insulin resistance and attenuate nephropathy in diabetic rats (Yuan et al. 2007). Moreover, lack of kininogen or kinin B2 receptor impaired insulin sensitivity and glucose tolerance in nondiabetic animals, indicating that the KKS is involved in insulin action and glucose homeostasis (Damas et al. 1999, Duka et al. 2001, Kakoki et al. 2010).
The KKS may enhance glucose metabolism through endothelium activation, vasodilation, increasing in blood flow, and delivery of energy substrates and hormones to tissues and by facilitating transcapillary glucose transport (Baron et al. 1994, Frossard et al. 2000). Bradykinin also increases glucose uptake in muscular cells and primary adipocytes by triggering GLUT4 (SLC2A4) translocation through insulin-dependent and -independent pathways (Isami et al. 1996, Rett et al. 1996, Kishi et al. 1998, Beard et al. 2006). However, in humans, the effect of kinins on muscle glucose uptake remains controversial (Dietze et al. 1996, Nuutila et al. 1996, Mahajan et al. 2004).

Although clinical and experimental studies have indicated that the KKS protects against the development of insulin resistance, the role of TK in glucose metabolism is not documented. Study of the role of KKS in diseases has been hampered by lack of suitable pharmacological inhibitors of TK. Recently, murine and human genetic 'models' of TK deficiency became available. The Klk1 gene, which encodes TK, has been inactivated in the mouse, resulting in the suppression of kinin formation (Meneton et al. 2001). In man, a major loss-of-function polymorphism of the Klk1 gene resulting in an inactivating mutation of the enzyme (R53H) has been described (Slim et al. 2002, Azizi et al. 2005). We evaluated the consequences for insulin sensitivity and glucose metabolism of lack of TK in mice with dietary (high-fat diet, HFD) or genetically (leptin mutation, $o b / o b$ trait) induced obesity and insulin resistance. We investigated the effects of the $R 53 H$-defective variant of TK on the metabolic status and incidence of insulin resistance and diabetes in a large population-based cohort.

\section{Materials and methods}

\section{Animal studies}

HFD model TK-deficient mice (Meneton et al. 2001) of 129/Sv-C57/BL6 genetic background and WT $\left(\mathrm{TK}^{+/+}\right)$ littermates received a standard chow diet (SD) or a HFD for 19 weeks, starting at 5 weeks of age. Four groups of mice, SD-TK ${ }^{+/+}(n=7)$, HFD-TK $^{+/+}(n=12)$, SD-TK $^{-/-}$ $(n=16)$, and HFD-TK ${ }^{-1-}(n=13)$ were studied. The standard diet contained $13.6 \%$ of calories from fat, $25.3 \%$ from protein, and $61.1 \%$ from carbohydrates (A03, SAFE, Augy, France). HFD contained $46.0 \%$ of calories from fat, $15.5 \%$ from protein, and $38.5 \%$ from carbohydrates (HF 235, SAFE).

Published by Bioscientifica Ltd. 
Genetic ob/ob model Experiments were carried out in double-mutant mice with deficiency in both $K l k 1$ and leptin genes on C57BL6 background. These mice were generated by breeding homozygous $\mathrm{TK}^{-1-}$ mice with heterozygous obese C57BL/6J $\operatorname{Lep}^{o b}(+/-)$ (Charles River Laboratory, Bar Harbor, ME, USA). The double-heterozygous mutants of the F1 generation were then intercrossed for four generations. The double-homozygous mutants $o b-\mathrm{TK}^{-1-}(n=7)$ were compared with $o b-\mathrm{TK}^{+/+}$ $(n=8)$ littermates.

All experiments were conducted in accordance with the European regulations for the care and use of laboratory animals (L 358-86/609/EEC) and were approved by the local ethic committee (Charles Darwin ethics committee for animal experimentation). All efforts were made to minimize animal suffering. The animals were killed by cervical dislocation. The mice were housed with a $12 \mathrm{~h}$ light: $12 \mathrm{~h}$ darkness cycle, and had free access to drinking water.

Metabolic studies Body weight was measured every 2 weeks. Glucose (GTT) and insulin (ITT) tolerance tests were carried out at 10 and 16 weeks after feeding initiation for the HFD protocol and at 13 and 19 weeks of age for the $o b / o b$ protocol. GTT was carried out by i.p. injection of $1 \mathrm{~g}$ glucose $/ \mathrm{kg}$ body weight after $5 \mathrm{~h}$ of fasting. ITT was carried out by injecting 0.5 (HFD protocol) or 1 unit $(o b / o b$ protocol) insulin/kg body weight. Blood samples were collected from the tail at $t=0,5,10,15,20,30,40,60,90$, and $120 \mathrm{~min}$. Glucose concentration was measured using a diagnostic glucometer from Lifescan Laboratories (Issyles-Moulineaux, France). Insulin concentration was measured at $t=0,15,30,60$, and 120 min by ELISA using mouse insulin as a standard (Millipore, Molsheim, France).

Body composition was measured in live animals by dual-energy X-ray absorptiometry (Piximus apparatus Lunar, Madison, WI, USA) in high-fat-fed mice only. Animals were killed at 24 and 22 weeks of age for HFD and $o b / o b$ models respectively and inguinal and mesenteric fat was collected and weighted.

Blood pressure measurements Systolic blood pressure and heart rate were monitored in conscious but restrained mice by tail-cuff plethysmography (BP2000, Visitech System, Bioseb, Vitrolles, France) at 18 weeks after initiation of feeding in the HFD protocol and at 20 weeks of age in the $o b / o b$ protocol. After 2 days of adaptation, measurements were performed for 3 consecutive days, between 1000 and $1200 \mathrm{~h}$. A set of 15 consecutive measurements were averaged for each mouse on each day and the mean of the three daily values was calculated.
Statistical analysis Data are expressed as mean \pm s.E.M. Statistical analyses were performed using ANOVA followed, when appropriate, using Fisher's protected least significant difference (PLSD) post hoc test for HFD protocol. Student's $t$-test was used for the $o b / o b$ protocol.
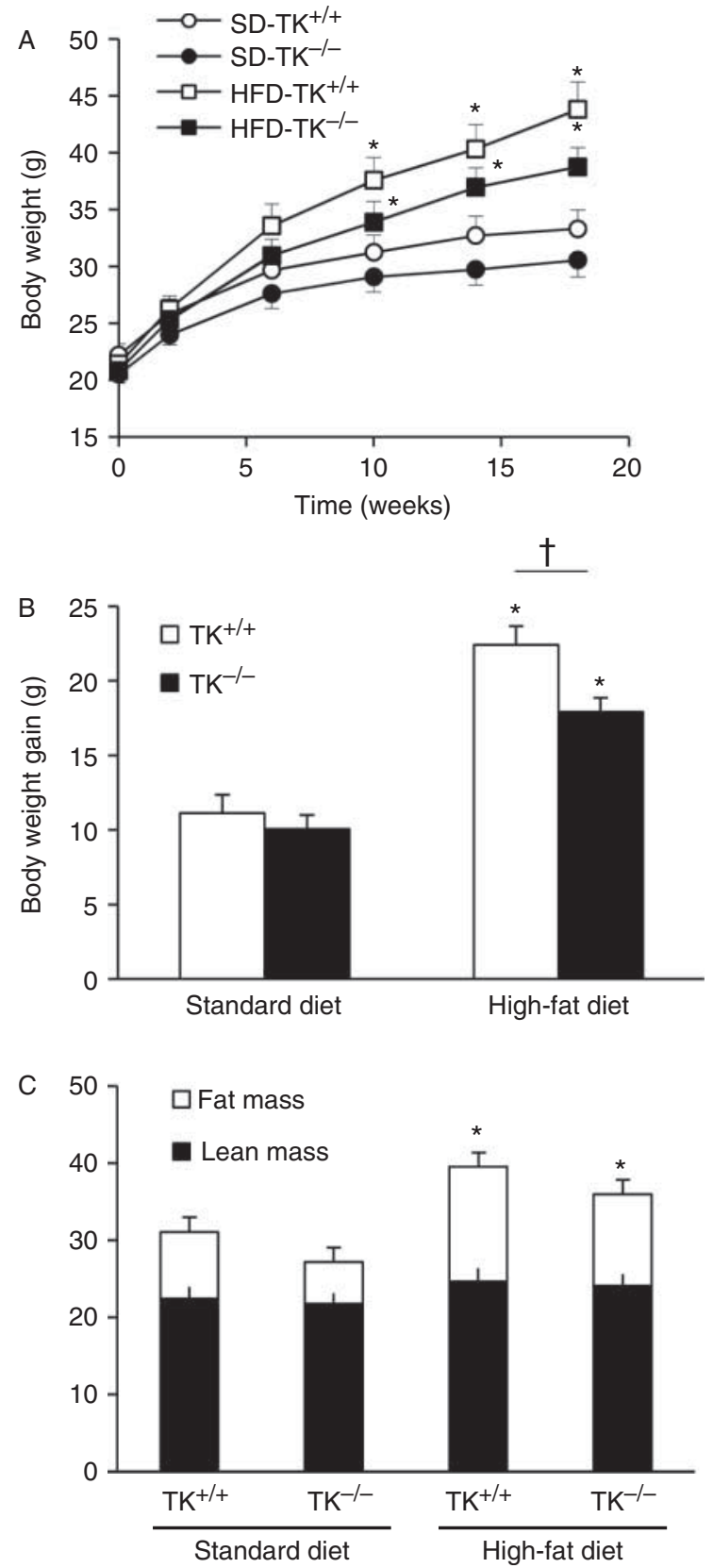

Figure 1

Body weight gain and fat mass of TK-deficient ( $\mathrm{TK}^{-1-}$ ) and control WT $\left(\mathrm{TK}^{+/+}\right)$mice fed standard (SD) or high-fat diet (HFD). Body weight (A), and body weight gain (B) during 19 weeks of diet. Fat and lean mass (C). Data are mean \pm S.E.M. $n=7-16$ per group. Two-way ANOVA followed by Fisher PLSD test, HFD vs SD: ${ }^{*} P<0.05 ; \mathrm{TK}^{-1-}$ vs $\mathrm{TK}^{+/+}:{ }^{\dagger} P<0.05$.

Published by Bioscientifica Ltd. 
A
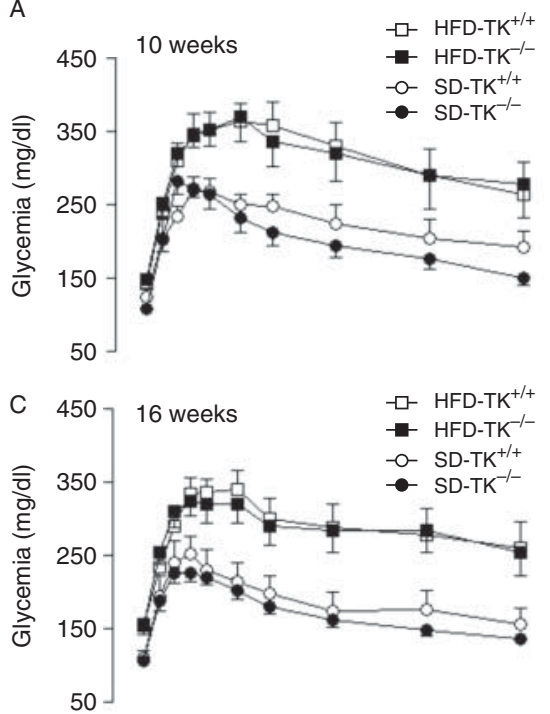

$E$

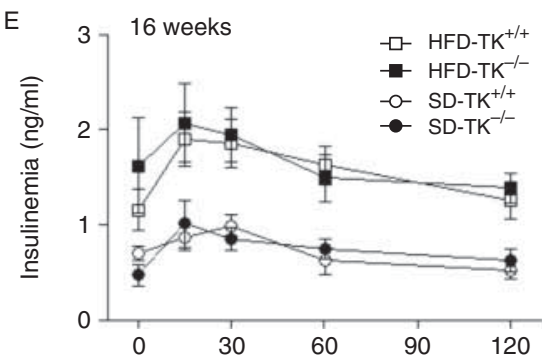

B

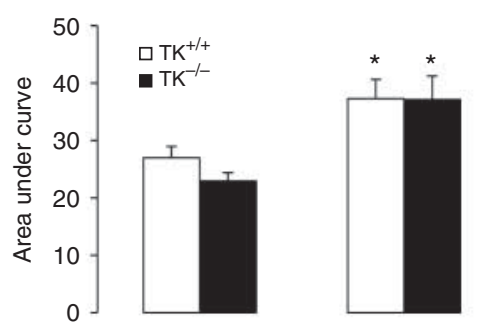

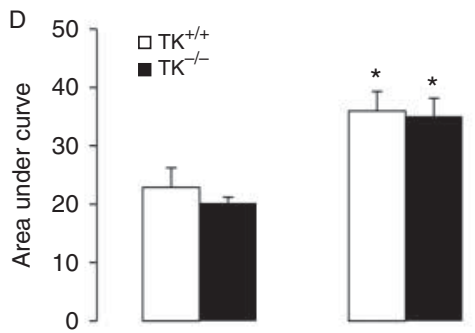

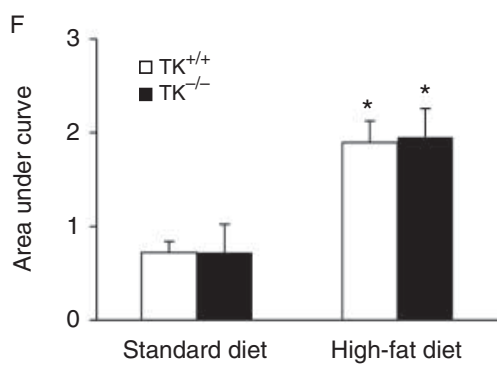

Figure 2

Glucose tolerance test in TK-deficient $\left(\mathrm{TK}^{-/-}\right)$and WT $\left(\mathrm{TK}^{+/+}\right)$mice fed standard (SD) or high-fat diet (HFD). Blood glucose concentration and area under the curve of glycemia at 10 weeks ( $A$ and $B$ ) and 16 weeks ( $C$ and $D$ ) of diet. Plasma insulin concentration and area under the curve of

The test of statistical power for rejecting a null hypothesis using the GraphPad StatMate program indicates that the study has $99 \%$ power for detecting a $27 \%$ difference in GTT among genotypes and $80 \%$ power for detecting a $20 \%$ difference. Significance was set at $P<0.05$.

\section{Human study}

The Data from Epidemiological Study on the Insulin Resistance syndrome (DESIR) is a 9-year prospective study conducted in 5212 men and women from the French general population (Balkau et al. 2008). Participants were recruited at ten healthcare centers in the western central part of France on the occasion of periodic health checkups offered by Social Security. The research protocol was approved by the ethics committee of Bicêtre Hospital and all participants signed an informed consent form. The study protocol included clinical and biological evaluations insulinemia at 16 weeks of diet (E and F). Data are mean \pm s.E.M. $n=7-16$ per group. Two-way ANOVA followed by Fisher PLSD test, HFD vs SD: $* P<0.05$; $\mathrm{TK}^{-1-}$ vs $\mathrm{TK}^{+/+}$: nonsignificant.

at inclusion and at visits at 3, 6, and 9 years of follow-up. Type 2 diabetes was defined as fasting plasma glucose (FPG) $\geq 7.0 \mathrm{mmol} / 1$ or as FPG $<7.0 \mathrm{mmol} / 1$ in the presence of treatment with an anti-diabetes drug. Participants with diabetes at baseline $(n=134,2.6 \%)$ were excluded from the analyses. Incident cases of type 2 diabetes were defined as subjects free of disease at entry who developed the disease at any time during the follow-up. The glycemic status of some participants ( $n=102,2.0 \%$ ) could not be ascertained at baseline and these patients were excluded from the analyses. Individuals without diabetes at baseline lost during follow-up and those for whom final glycemic status could not be determined $(n=1148,22.0 \%)$ were excluded from analysis of incidence. Weight and height were measured by trained personnel. Venous blood samples were collected in the morning after the subjects had fasted for $12 \mathrm{~h}$. Systolic and diastolic blood pressures were measured with a mercury sphygmomanometer adapted

Published by Bioscientifica Ltd. 

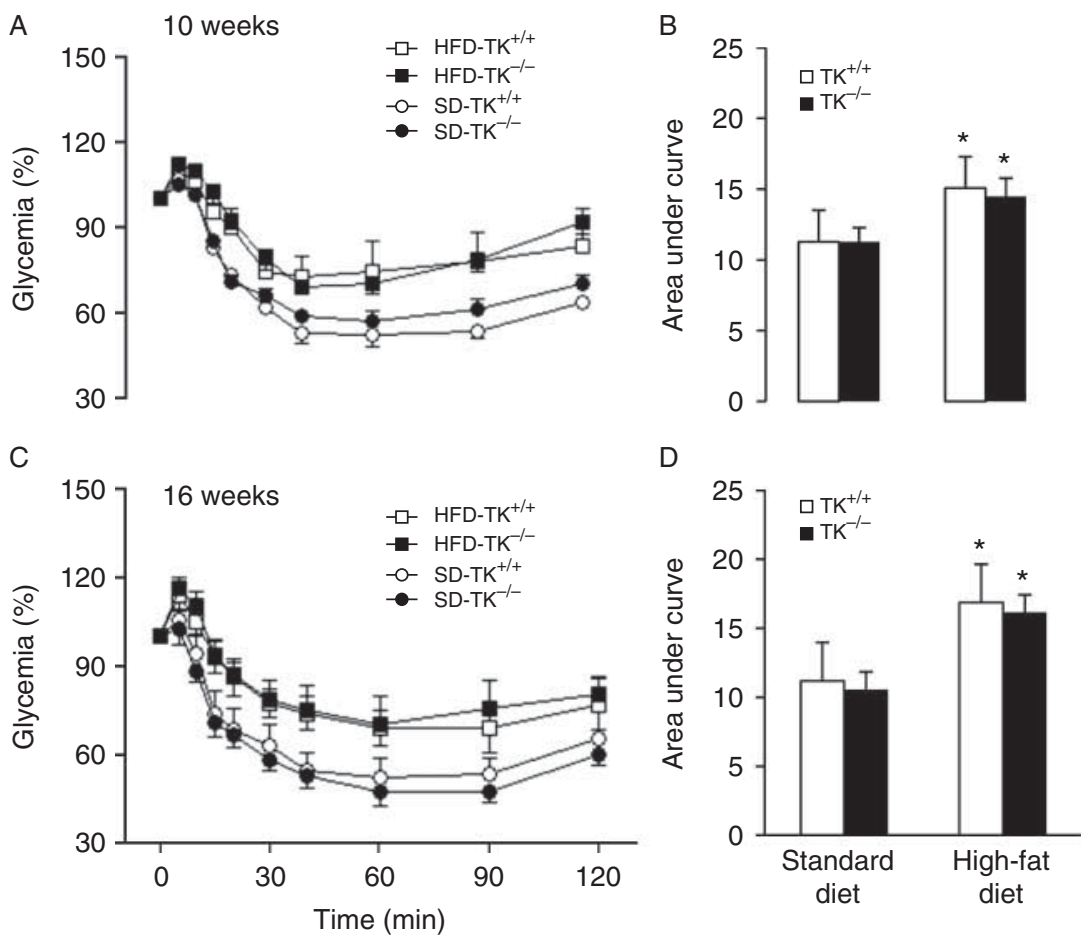

Figure 3

Insulin tolerance test (ITT) in TK-deficient $\left(\mathrm{TK}^{-1-}\right)$ and WT $\left(\mathrm{TK}^{+/+}\right)$mice fed standard (SD) or high-fat diet (HFD). Relative values of the ITT and area under the curve of glycemia at 10 weeks ( $A$ and $B$ ) and 16 weeks ( $C$ and $D$ )

for arm size after $5 \mathrm{~min}$ of rest in a supine position. Results of two consecutive measurements were averaged, for analysis. A detailed description of laboratory measurements including glucose and insulin is provided elsewhere (Balkau et al. 2008). Homeostasis model assessment index of insulin sensitivity (HOMA-IR), based on fasting levels of glucose and insulin, was computed using the Microsoft Excel spreadsheet implementation of the HOMA calculator (v2.2) available at www.dtu.ox.ac.uk/Homacalculator/ download.php (accessed 1 March 2006). Creatinine clearance was calculated according to the Modification of Diet in Renal Disease formula (Levey et al. 1999).

R53H genotyping The G230A (rs5515 coding for $R 53 H$ ) SNP of the TK gene, $h K L K 1$, located on chromosome 19 (19q13.2-q13.4) was genotyped using the Assay by Design kit from Applied Biosystems (Life Technologies SAS) (Slim et al. 2002). The conditions for TaqMan reactions were as follows: $50{ }^{\circ} \mathrm{C}$ for $2 \mathrm{~min}, 95^{\circ} \mathrm{C}$ for $15 \mathrm{~min}$, and 45 cycles of $90{ }^{\circ} \mathrm{C}$ for $15 \mathrm{~s}$ and $60{ }^{\circ} \mathrm{C}$ for $1 \mathrm{~min}$.

Statistical analysis comparisons were made between genotype $R R$ ( $R 53$ homozygotes) and $H$ allele carriers of diet. Data are mean \pm s.E.M. $n=7-16$ per group. Two-way ANOVA followed by Fisher PLSD test, HFD vs SD: ${ }^{\star} P<0.05$; $\mathrm{TK}^{-1-}$ vs $\mathrm{TK}^{+1+}$ : nonsignificant.

(genotypes $R H+H H, R 53 H$ heterozygotes and $H 53$ homozygotes) because of the rare frequency of homozygous $H H$ subjects $(n=6)$. Baseline characteristics were compared among genotypes using the $\chi^{2}$ test for categorical variables, and ANCOVA for continuous variables including sex and age as covariables. Genotype associations with incidence of diabetes during follow-up were assessed by logistic regression models. ANCOVA for repeated measurements was used to compare evolution of clinical and

Table 1 Blood pressure and heart rate in WT $\left(\mathrm{TK}^{+/+}\right)$and TK-deficient $\left(\mathrm{TK}^{-1-}\right)$ mice fed standard or high-fat diet for 18 weeks. Data are mean \pm s.E.M.

\begin{tabular}{|c|c|c|c|c|}
\hline & \multicolumn{2}{|c|}{ Standard diet } & \multicolumn{2}{|c|}{ High-fat diet } \\
\hline & $\mathrm{TK}^{+/+}$ & $\mathrm{TK}^{-1-}$ & $\mathrm{TK}^{+/+}$ & $\mathrm{TK}^{-1}$ \\
\hline$n$ & 7 & 16 & 12 & 13 \\
\hline $\mathrm{SBP}(\mathrm{mmHg})$ & $108 \pm 4$ & $116 \pm 3$ & $113 \pm 4$ & $109 \pm 3$ \\
\hline DBP (mmHg) & $76 \pm 6$ & $83 \pm 3$ & $75 \pm 4$ & $80 \pm 4$ \\
\hline Heart rate (bpm) & $594 \pm 16$ & $587 \pm 12$ & $655 \pm 5^{*}$ & $646 \pm 11 *$ \\
\hline
\end{tabular}

SBP, systolic blood pressure; DBP, diastolic blood pressure. Two-way ANOVA followed by Fisher PLSD test, high-fat vs standard diet: ${ }^{*} P<0.05 ; \mathrm{TK}^{-1-}$ vs $\mathrm{TK}^{+\prime+}$.

Published by Bioscientifica Ltc. 
biological variables at $0,3,6$, and 9 years of follow-up. Skewed variables (insulinemia, HOMA-IR) were logtransformed before statistical analyses. All analyses were adjusted on sex, age, BMI, and FPG at baseline. Results are expressed as mean \pm s.D. $P<0.05$ was considered significant. Statistics were analysed using Statview (SAS Institute, Cary, NC, USA). The test of statistical power for rejecting a null hypothesis using the GraphPad StatMate program indicates that the study has $99 \%$ power for detecting a $4 \%$ difference in BMI, or a $3 \%$ difference in FPG or a $16 \%$ difference in insulinemia between genotypes at baseline.

\section{Results}

\section{Animal studies}

HFD-fed model As expected, HFD animals were significantly heavier and had larger weight increases than SD animals (Fig. 1A and B). No difference in body weight was observed between $\mathrm{TK}^{+/+}$and $\mathrm{TK}^{-1-}$ mice under $\mathrm{SD}$, but after 19 weeks of $\mathrm{HFD}, \mathrm{TK}^{-1-}$ mice had gained $20 \%$ less weight $(P<0.05)$ and tended to have lower fat mass $(P=0.06)$ than $\mathrm{TK}^{+/+}$(Fig. 1C).

Fasting glucose level and area under the curve (AUC) of glucose during GTT were significantly higher in HFD mice than SD mice at 10 and 16 weeks for both genotypes. No effect of genotype was observed in HFD and SD groups (Fig. 2A, B, C, and D). In HFD mice, insulin release was significantly increased during GTT compared with SD mice, but there was no genotype effect (Fig. 2D and E). Similarly, glucose response during ITT at 10 and 16 week was higher in the HFD than in the SD group, but no effect of genotype was observed (Fig. 3). Diet and genotype had no significant effect on blood pressure. Heart rate was significantly increased in HFD mice compared with SD mice, in both $\mathrm{TK}^{-/-}$and in $\mathrm{TK}^{+/+}$mice $(P<0.05$, Table 1$)$.

Genetic $\mathbf{o b} / \mathbf{b} b$ model Body weight and weight gain were similar in $o b-\mathrm{TK}^{+/+}$and $o b-\mathrm{TK}^{-1-}$ mice (Fig. 4). There was no difference between $o b-\mathrm{TK}^{+/+}$and $o b-\mathrm{TK}^{-/-}$for fasting glucose and AUC of glucose (Fig. 5), as well as for insulin during GTT (not shown). Glucose response during ITT was similar in the two groups (Fig. 6). No difference was seen between $o b-\mathrm{TK}^{+1+}$ and $o b-\mathrm{TK}^{-1-}$ mice in inguinal and mesenteric fat mass. There was no effect of TK deficiency on systolic blood pressure $(107 \pm 5$ vs $115 \pm 3 \mathrm{mmHg}$ in ob-TK ${ }^{-1-}$ vs ob-TK ${ }^{+/+}$mice respectively) and heart rate $\left(539 \pm 76\right.$ vs $575 \pm 21$ bpm in ob-TK ${ }^{-/-}$vs ob-TK ${ }^{+/+}$mice respectively) (Supplementary Fig. 1 and Table 1, see section on supplementary data given at the end of this article).

\section{Human studies}

Baseline characteristics Genotypes were available for 4950 of the 5110 participants with known diabetic status at baseline (genotyping failure rate 3.1\%). Among these 4950 individuals, 132 had diabetes at baseline. The proportion of $R R$ and $R H+H H$ genotypes did not differ significantly according to diabetes at baseline (of the participants with the $R R$ genotype: 122 (2.6\%) had and 4465 (97.4\%) did not have diabetes respectively, of the participants with the $R H$ or $H H$ genotypes: 10 (2.7\%) had and 353 (97.3\%) did not have diabetes respectively, $P=0.91)$.

Table 2 summarizes the demographic features and clinical and metabolic profiles at baseline of the population without diabetes at baseline, according to $\mathrm{R} 53 \mathrm{H}$ genotypes. Rare variant (H53-coding) allelic frequency was 3.93 and $3.60 \%$, in men and women respectively $(P=0.49)$. Genotype distributions were in Hardy-Weinberg equilibrium. Six subjects were homozygotes for the H53 variant, while 346 were heterozygotes. There was no significant association of the $53 \mathrm{H}$-coding allele with
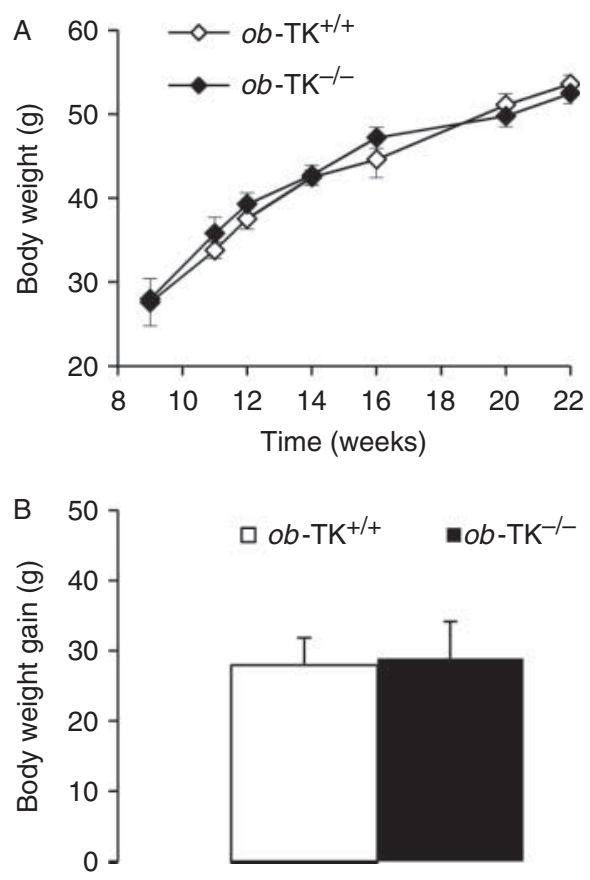

\section{Figure 4}

Body weight gain in ob/ob TK-deficient mice (ob-TK ${ }^{-1-}$ ) and ob/ob control $\left(o b-\mathrm{TK}^{+/+}\right)$mice. Body weight $(\mathrm{A})$ and body weight gain (B) between 9 and 22 weeks of age. Data are mean \pm s.E.M. $n=7-8$ per group.

Published by Bioscientifica Ltd. 
weight, BMI, markers of abdominal obesity, FPG, fasting insulinemia, HOMA-IR, and blood pressure. The proportion of patients taking ACE inhibitors or angiotensin receptor blockers was low (3.4\%) and did not differ among genotype ( 3.3 vs $3.6 \%, P=0.59$ in the $R R$ and $R H+H H$ groups respectively). The distribution of the $R R$ and $R H+$ $H H$ genotypes in overweight or obese subject was similar compared with overall population ( $R R$ 92.4\%, $R H+H H$ $7.6 \%$ in overweight subjects, $P=0.73$ vs overall population, $R R$ 92.3\%, $R H+H H 7.7 \%$ in obese subjects, $P=0.85$ vs overall population). We did not observe any TK genotype-related difference in metabolic or cardiovascular parameters at baseline or during follow-up in overweight or obese subjects (data not shown).

Follow-up study Changes in BMI, FPG, fasting insulinemia, systolic blood pressure, and heart rate over time did not differ according to TK genotype (Table 3). Among the 4818 people, without diabetes at baseline, for whom genotype data was available, a total of 193 subjects developed diabetes, with no association with $R 53 H$ genotype: 180 had the $R R$ genotype (4.0\% of all the $R R$ genotype carriers) and 13 had the $R H$ or $H H$ genotypes (3.7\% of the carriers of these genotypes), $P=0.76$.

\section{Discussion}

The present data show that TK haploinsufficiency in middle-aged humans and TK deficiency in mice with dietary or genetically induced obesity do not significantly influence the development of insulin resistance and associated metabolic and hemodynamic abnormalities.

\section{Animal study}

Obesity is a hallmark of the HFD and $o b / o b$ mice models (Tschop \& Heiman 2002). Our data indicate that TK deficiency altered weight gain in the HFD but not in the $o b / o b$ mouse model. Similar results were observed in a mouse model of kinin B1 receptor deficiency (Mori et al. 2008). Resistance to obesity in B1 receptor-deficient animals was suggested to be due to increased leptin sensitivity, and therefore absent in mice lacking leptin (Mori et al. 2008). Our data for TK-deficient mice are consistent with this hypothesis.

In the present study, absence of TK and TK-derived kinins did not alter glucose tolerance, insulin sensitivity, and insulin release assessed by GTT or ITT responses, in the two models of obesity and insulin resistance. We cannot exclude that an effect on insulin sensitivity could have
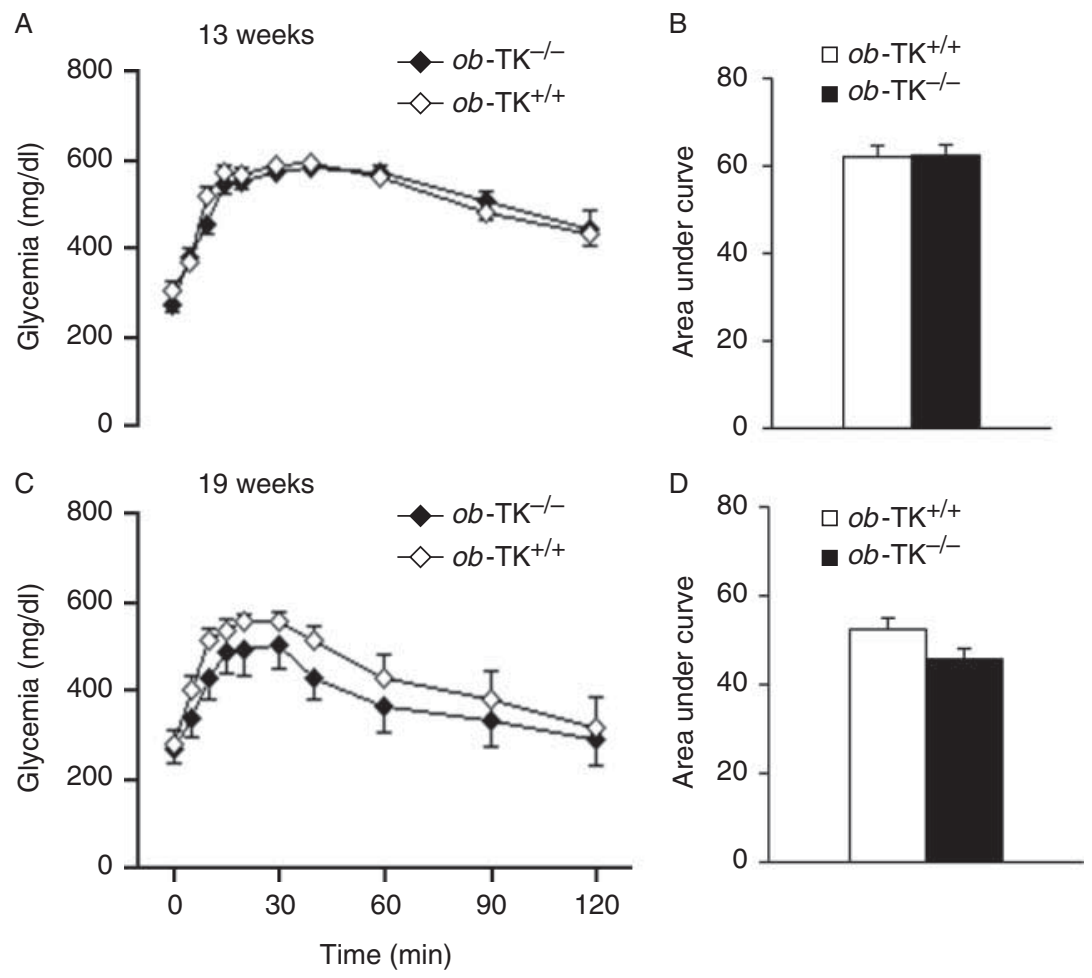

Figure 5

Responses to glucose tolerance test of ob/ob TK-deficient mice (ob-TK ${ }^{-1-}$ ) and ob/ob control mice (ob-TK $\left.{ }^{+/+}\right)$. Blood glucose concentration and area under curve of glycemia at 13 weeks ( $A$ and $B$ ) and 19 weeks (C and D) of age. Data mean \pm s.E.M. $n=7-8$ per group.

http://joe.endocrinology-journals.org DOI: $10.1530 / \mathrm{JOE}-13-0529$ (c) 2014 Society for Endocrinology Printed in Great Britain
Published by Bioscientifica Ltd. 

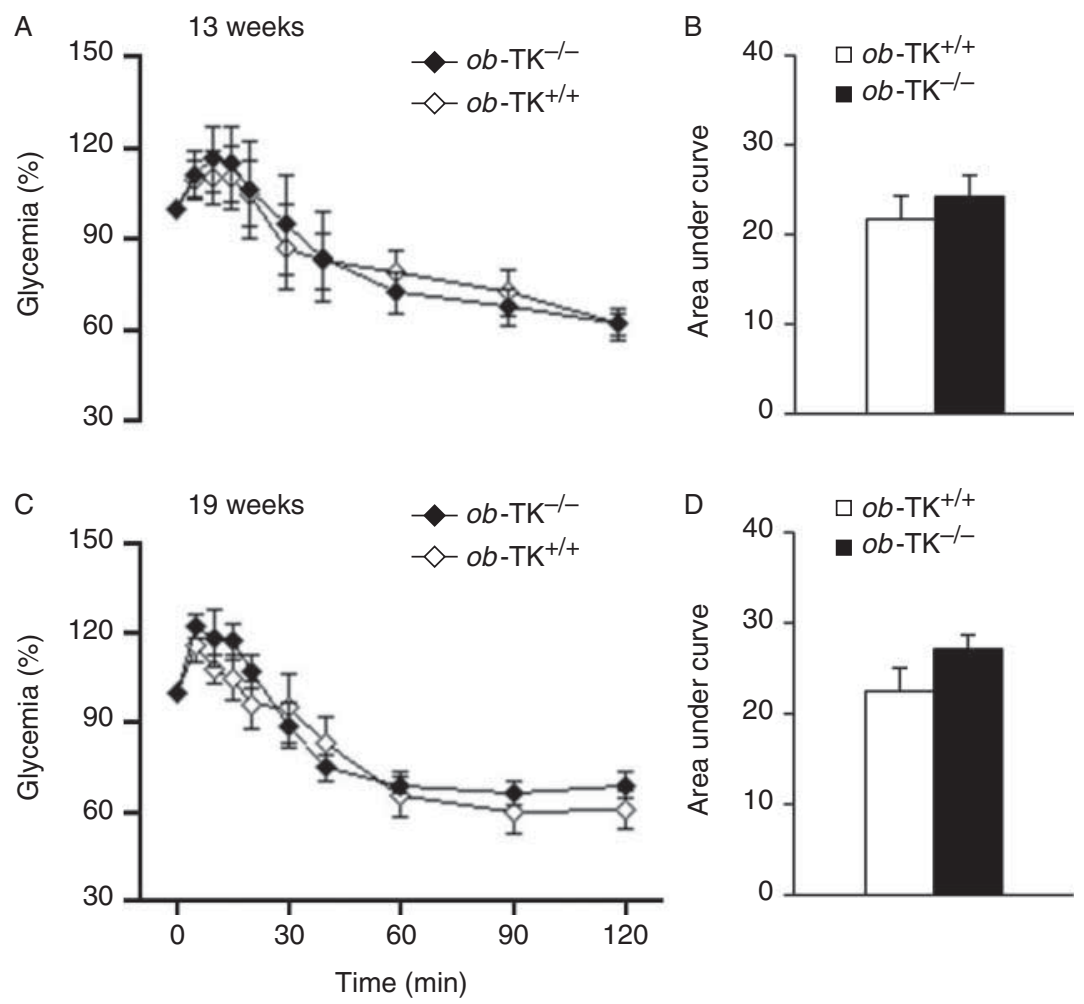

\section{Figure 6}

Insulin tolerance test (ITT) in ob/ob TK-deficient mice $\left(o b-\mathrm{TK}^{-1-}\right)$ and control ob/ob $\left(o b-\mathrm{TK}^{+/+}\right)$mice. Relative values of the ITT and area under the curve of glycemia at 13 weeks ( $A$ and $B$ ) and 19 weeks ( $C$ and D) of age. Data are mean \pm s.E.M. $n=7-8$ per group.

been detected by using hyperinsulinemic-euglycemic clamps, but such an effect, if any, would be small and of unknown physiological significance. These negative observations may, however, not be inconsistent with results from previous studies documenting the effects of kinins B1 and B2 receptors on insulin secretion or action. Indeed, these studies indicate that kinin receptors may exhibit isoform-specific differences in the modulation of metabolic processes. Mice lacking B1 receptor, fed standard diet, exhibited pancreas abnormalities, characterized by fewer pancreatic islets and lower insulin content, associated with hypoinsulinemia and reduced insulin secretion after glucose load (Araujo et al. 2006). Mori et al. (2012) suggested facilitation of insulin action in adipocytes by the $\mathrm{B} 1$ receptor, leading to fat accumulation and insulin resistance in response to HFD. The deleterious effect of B1 receptor in pancreas and adipocytes may be mediated by the role of this receptor in inflammation (Catanzaro et al. 2010), a process involved in pathogenesis of type 2 diabetes. Pharmacological blockade of the B1 receptor decreased inflammatory markers of obesity and reversed metabolic abnormalities and insulin resistance by
Table 2 Demographic features and clinical and metabolic profiles of the DESIR population without diabetes at baseline according to tissue kallikrein rs5515 (R53H) genotype. Data are mean \pm S.E.M. except for HOMA-IR and insulinemia which are medians (interquartile range). Comparison was made by Student's $t$-test for continuous variables or $\chi^{2}$ test for categorical variables when appropriate

\begin{tabular}{|c|c|c|c|}
\hline & $\boldsymbol{R R}$ & $\boldsymbol{R H}+\boldsymbol{H H}$ & $\boldsymbol{P}$ \\
\hline Number (\%) & $4485(92.6)$ & $358(7.4)$ & \\
\hline Age (years) & $46.7 \pm 10.0$ & $46.3 \pm 10.3$ & 0.48 \\
\hline Sex male $n(\%)$ & $2210(49.2)$ & $183(51.1)$ & 0.49 \\
\hline Weight (kg) & $68.2 \pm 12.8$ & $67.6 \pm 12.9$ & 0.22 \\
\hline BMI $\left(\mathrm{kg} / \mathrm{m}^{2}\right)$ & $24.6 \pm 3.8$ & $24.4 \pm 3.7$ & 0.16 \\
\hline Waist-to-hip ratio & $0.85 \pm 0.09$ & $0.85 \pm 0.9$ & 0.26 \\
\hline FPG $(\mathrm{mmol} / \mathrm{l})$ & $5.31 \pm 0.64$ & $5.29 \pm 0.56$ & 0.12 \\
\hline HOMA-IR & $0.87(0.62)$ & $0.87(0.64)$ & 0.15 \\
\hline Insulinemia (pmol/l) & $39.5(27.7)$ & $39.4(29.0)$ & 0.15 \\
\hline eGFR $\left(\mathrm{ml} / \mathrm{min} .1 .73 \mathrm{~m}^{2}\right)$ & $83.3 \pm 14.0$ & $84.1 \pm 13.5$ & 0.47 \\
\hline $\mathrm{SBP}(\mathrm{mmHg})$ & $131 \pm 16$ & $130 \pm 14$ & 0.24 \\
\hline $\mathrm{DBP}(\mathrm{mmHg})$ & $80 \pm 10$ & $79 \pm 9$ & 0.37 \\
\hline HR (bpm) & $67.3 \pm 10.0$ & $67.9 \pm 10.2$ & 0.25 \\
\hline
\end{tabular}

FPG, fasting plasma glucose; eGFR, estimated glomerular filtration rate SBP, systolic blood pressure; DBP, diastolic blood pressure; HR, heart rate. $R H$, heterozygous subjects $(n=351) ; H H$, homozygous subjects $(n=7)$. 


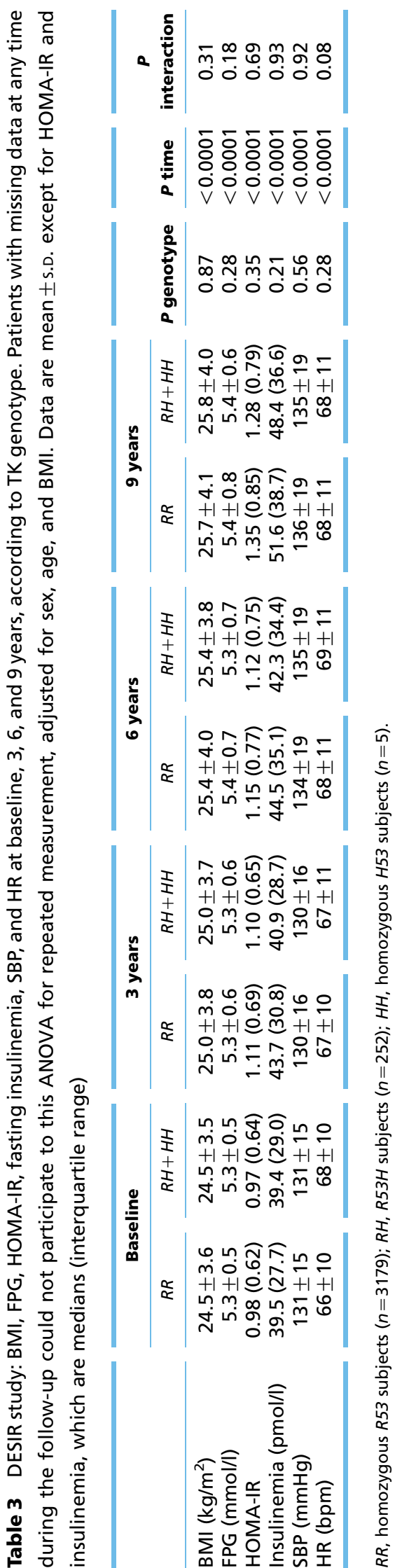

http://joe.endocrinology-journals.org DOI: $10.1530 /$ JOE-13-0529
(C) 2014 Society for Endocrinology Printed in Great Britain reducing oxidative stress in glucose-fed rats (Dias \& Couture 2012). On the other hand, B2 receptor activation may have beneficial effects on glucose metabolism. Lack of B2 receptor in mice impaired insulin-dependent glucose transport (Duka et al. 2001) and increased hepatic glucose production (Barros et al. 2012a) leading to a state of insulin resistance. In rats, a $\mathrm{B} 2$ receptor antagonist reduced glucose uptake and insulin sensitivity (Kohlman et al. 1995). Loss of both B1 and B2 receptor signaling in TK-deficient mice may result in a null phenotype for glucose metabolism in our model.

On the other hand, while TK is the main source of kinins in healthy mice (Meneton et al. 2001), other kininforming enzymes might be activated in the setting of obesity and become the principal source of kinins, while this remains speculative. Plasma prekallikrein (or kallikrein B), a potential kinin-forming enzyme present in an inactive form in healthy mice, was found to be activated in insulinopenic diabetic rats (Rothschild et al. 1999, Tschope et al. 1999), but no data are available concerning obesity and insulin resistance.

Male mice, deficient in both B1 and B2 receptor, studied at 12 months of age, display mild hyperinsulinemia with normal glucose levels, indicating mild insulin resistance (Kakoki et al. 2010). In ob/ob mice made deficient in both kinin receptors, mild hyperglycemia; enhanced insulin release; and hepatic abnormalities have been reported (Barros et al. 2012b). The discrepancy between the $\mathrm{TK}$ and the $\mathrm{B} 1 / \mathrm{B} 2$ receptor-deficient mice may be related to the use of different experimental conditions, especially sex and duration of the study. Indeed in the Barros et al. (2012b) study, the difference in glucose tolerance between WT mice and mice lacking B1 and B2 receptors was observed only in 6-month-old female mice and not in younger animals. Nevertheless, we did not observe any difference in glucose parameters between $o b-\mathrm{TK}^{+/+}$and $o b-\mathrm{TK}^{-/-}$when we carried out GTT and ITT in 12-month-old mice. The difference between TK and $\mathrm{B} 1 / \mathrm{B} 2$ receptor-deficient mice may also be explained by the role of putative non-TK kinin-forming enzymes, as discussed earlier.

Although obesity and insulin resistance are associated with hypertension in humans, we observed no difference in blood pressure between C57Bl6 mice fed either the HFD or the SD. This is in agreement with the previous observations made in this model (Williams et al. 2003, Belin de Chantemele et al. 2011). The increase in heart rate in HFD mice is probably due to leptin-mediated sympatho-activation (Belin de Chantemele et al. 2011). Indeed, no difference in heart rate was observed between

Published by Bioscientifica Ltd. 
$o b-\mathrm{TK}^{+/+}$and $o b-\mathrm{TK}^{-/-}$mice. TK deficiency had no effect on blood pressure in HFD or in $o b / o b$ mice, indicating that TK does not play any antihypertensive role in these models, contrary to other pro-hypertensive mice models related to sodium retention (Waeckel et al. 2012).

\section{Human study}

The relevance of our experimental findings to human pathophysiology was assessed by investigating the impact of a loss-of-function polymorphism of the TK gene $(R 53 H)$ on the incidence of insulin resistance and diabetes in a general population cohort. The DESIR study is a largecohort study with 9 years of follow-up aimed at identifying genetic and nongenetic determinants of insulin resistance and type 2 diabetes (Balkau et al. 2008). The G to A transition mutation in exon 3 of the TK gene results in the substitution of His to Arg at position 53 in the amino acid sequence of TK and which reduces dramatically (>90\%) the kinin-forming activity of the enzyme (Slim et al. 2002). We have shown that the defective $53 \mathrm{H}$ variant of TK did not affect the incidence of insulin resistance and diabetes in the DESIR cohort.

Few human studies have been conducted to date on KKS and risk of metabolic diseases. A common variant of the $A C E$ (kininase II), gene associated with high ACE levels and presumably reduced concentrations of kinins, has been linked to the risk of insulin resistance in a large cohort, but angiotensin may be also involved in this effect (Bonnet et al. 2008). Promoter variations in the $\mathrm{B} 2$ receptor gene have been linked to risk of insulin resistance or diabetes in smaller populations (Fallo et al. 2004, Alvim Rde et al. 2012). However, the functionality of these genetic variants was not documented. The present study indicates that TK, despite its genetic variability, is not involved in genetic susceptibility to insulin resistance and diabetes. These human data are consistent with the mouse data.

A limitation of the human study is the low number of homozygote subjects, due to the allelic frequency (0.03) of the defective variant. While $6-7 \%$ of subjects in white populations are heterozygous, homozygous subjects are very rare $(0.05 \%)$ (Slim et al. 2002). Accordingly, mainly heterozygous subjects only partially deficient in TK were studied. However, heterozygous subjects have reduced urinary kallikrein activity and an arterial phenotype (Azizi et al. 2005).

In conclusion, we have shown that genetic deficiency in TK activity, partial in man or complete in mice, has no influence on the development of insulin resistance and diabetes. The TK-kinin system does not seem to participate in the control of insulin sensitivity in mouse models of obesity. Our results do not exclude an effect of kinin receptors, indicated by previous studies. It seems that B1R and B2R have opposite effects on glucose homeostasis. Therefore, the absence of stimulation of both in TK deficiency could lead to the neutral effect observed in our study. The present data also does not exclude an effect of kinins in situations where kinin levels increase as a consequence of impaired catabolism, like ACE inhibition.

\section{Supplementary data}

This is linked to the online version of the paper at http://dx.doi.org/10.1530/ JOE-13-0529.

\section{Declaration of interest}

$L P, L W, F A-G, R R$, and N B hereby declare a duality of interest in view of the patent submitted for the use of peptide kinin B1 and B2 receptor agonists in the prevention or treatment of ischemia-related organ damage (No EP12305349). F F, S B, M F, C C, N B, F B, G G, G V, and M M declare that there is no conflict of interest that could be perceived as prejudicing the impartiality of the research reported.

\section{Funding}

This work was supported by the Institut National de la Sante Et de la Recherche Médicale, the Universities Paris-Descartes, Pierre and Marie Curie and Paris Diderot, and grants from the Association Française des Diabétiques and the Fondation pour la Recherche Médicale.

\section{Acknowledgements}

The authors are grateful to Georges Zadigue (INSERM U872, Paris) for his contribution to some parts of this study.

\section{References}

Abuissa H, Jones PG, Marso SP \& O'Keefe JH Jr 2005 Angiotensinconverting enzyme inhibitors or angiotensin receptor blockers for prevention of type 2 diabetes: a meta-analysis of randomized clinical trials. Journal of the American College of Cardiology 46 821-826. (doi:10.1016/j.jacc.2005.05.051)

Alvim Rde O, Santos PC, Nascimento RM, Coelho GL, Mill JG, Krieger JE \& Pereira AC 2012 BDKRB2+9/-9 polymorphism is associated with higher risk for diabetes mellitus in the Brazilian general population. Experimental Diabetes Research 2012 480251. (doi:10.1155/2012/ 480251)

Araujo RC, Mori MA, Merino VF, Bascands JL, Schanstra JP, Zollner RL, Villela CA, Nakaie CR, Paiva AC, Pesquero JL et al. 2006 Role of the kinin $\mathrm{B}_{1}$ receptor in insulin homeostasis and pancreatic islet function. Biological Chemistry 387 431-436. (doi:10.1515/BC.2006.057)

Azizi M, Boutouyrie P, Bissery A, Agharazii M, Verbeke F, Stern N, Bura-Riviere A, Laurent S, Alhenc-Gelas F \& Jeunemaitre X 2005 Arterial and renal consequences of partial genetic deficiency in tissue kallikrein

Published by Bioscientifica Ltd. 
activity in humans. Journal of Clinical Investigation 115 780-787. (doi:10. 1172/JCI200523669)

Balkau B, Lange C, Fezeu L, Tichet J, de Lauzon-Guillain B, Czernichow S, Fumeron F, Froguel P, Vaxillaire M, Cauchi S et al. 2008 Predicting diabetes: clinical, biological, and genetic approaches: data from the Epidemiological Study on the Insulin Resistance Syndrome (DESIR). Diabetes Care 31 2056-2061. (doi:10.2337/dc08-0368)

Baron AD, Steinberg H, Brechtel G \& Johnson A 1994 Skeletal muscle blood flow independently modulates insulin-mediated glucose uptake. American Journal of Physiology 266 E248-E253.

Barros CC, Haro A, Russo FJ, Schadock I, Almeida SS, Reis FC, Moraes MR, Haidar A, Hirata AE, Mori M et al. 2012a Bradykinin inhibits hepatic gluconeogenesis in obese mice. Laboratory Investigation 92 1419-1427. (doi:10.1038/labinvest.2012.105)

Barros CC, Haro A, Russo FJ, Schadock I, Almeida SS, Ribeiro RA, Vanzela EC, Lanzoni VP, Barros FC, Moraes MR et al. 2012b Altered glucose homeostasis and hepatic function in obese mice deficient for both kinin receptor genes. PLOS ONE 7 e40573. (doi:10.1371/journal.pone. 0040573)

Beard KM, Lu H, Ho K \& Fantus IG 2006 Bradykinin augments insulinstimulated glucose transport in rat adipocytes via endothelial nitric oxide synthase-mediated inhibition of Jun $\mathrm{NH}_{2}$-terminal kinase. Diabetes 55 2678-2687. (doi:10.2337/db05-1538)

Belin de Chantemele EJ, Mintz JD, Rainey WE \& Stepp DW 2011 Impact of leptin-mediated sympatho-activation on cardiovascular function in obese mice. Hypertension 58 271-279. (doi:10.1161/HYPERTENSIONAHA.110.168427)

Bergaya S, Hilgers RH, Meneton P, Dong Y, Bloch-Faure M, Inagami T, Alhenc-Gelas F, Levy BI \& Boulanger CM 2004 Flow-dependent dilation mediated by endogenous kinins requires angiotensin AT2 receptors. Circulation Research 94 1623-1629. (doi:10.1161/01.RES.0000131497. 73744.1a)

Bonnet F, Patel S, Laville M, Balkau B, Favuzzi A, Monti LD, Lalic N \& Walker M 2008 Influence of the ACE gene insertion/deletion polymorphism on insulin sensitivity and impaired glucose tolerance in healthy subjects. Diabetes Care 31 789-794. (doi:10.2337/dc07-1788)

Bosch J, Yusuf S, Gerstein HC, Pogue J, Sheridan P, Dagenais G, Diaz R, Avezum A, Lanas F, Probstfield J et al. 2006 Effect of ramipril on the incidence of diabetes. New England Journal of Medicine 355 1551-1562. (doi:10.1056/NEJMoa065061)

Buleon M, Allard J, Jaafar A, Praddaude F, Dickson Z, Ranera MT, Pecher C, Girolami JP \& Tack I 2008 Pharmacological blockade of B2-kinin receptor reduces renal protective effect of angiotensin-converting enzyme inhibition in $o b / o b$ mice model. American Journal of Physiology. Renal Physiology 294 F1249-F1256. (doi:10.1152/ajprenal.00501.2007)

Catanzaro OL, Dziubecki D, Obregon P, Rodriguez RR \& Sirois P 2010 Antidiabetic efficacy of bradykinin antagonist R-954 on glucose tolerance test in diabetic type 1 mice. Neuropeptides $\mathbf{4 4}$ 187-189. (doi:10.1016/j.npep.2009.12.010)

Damas J, Bourdon V \& Lefebvre PJ 1999 Insulin sensitivity, clearance and release in kininogen-deficient rats. Experimental Physiology 84 549-557. (doi:10.1111/j.1469-445X.1999.01812.x)

Dias JP \& Couture R 2012 Blockade of kinin $B_{1}$ receptor reverses plasma fatty acids composition changes and body and tissue fat gain in a rat model of insulin resistance. Diabetes, Obesity \& Metabolism 14 244-253. (doi:10.1111/j.1463-1326.2011.01521.x)

Dietze GJ, Wicklmayr M, Rett K, Jacob S \& Henriksen EJ 1996 Potential role of bradykinin in forearm muscle metabolism in humans. Diabetes 45(Suppl 1) S110-S114. (doi:10.2337/diab.45.1.S110)

Duka I, Shenouda S, Johns C, Kintsurashvili E, Gavras I \& Gavras H 2001 Role of the $\mathrm{B}_{2}$ receptor of bradykinin in insulin sensitivity. Hypertension 38 1355-1360. (doi:10.1161/hy1201.096574)

Fallo F, Mulatero P, Vettor R, Scarda A, Della Mea P, Morello F, Veglio F \& Williams TA 2004 Bradykinin $\mathrm{B}_{2}$ receptor gene C-58T polymorphism and insulin resistance. A study on obese patients. Hormone and Metabolic Research 36 243-246. (doi:10.1055/s-2004-814457)

http://joe.endocrinology-journals.org DOI: $10.1530 / J O E-13-0529$
(C) 2014 Society for Endocrinology Printed in Great Britain
Frossard M, Joukhadar C, Steffen G, Schmid R, Eichler HG \& Muller M 2000 Paracrine effects of angiotensin-converting-enzyme- and angiotensin-II-receptor- inhibition on transcapillary glucose transport in humans. Life Sciences 66 PL147-PL154. (doi:10.1016/S00243205(99)00679-7)

Griol-Charhbili V, Messadi-Laribi E, Bascands JL, Heudes D, Meneton P, Giudicelli JF, Alhenc-Gelas F \& Richer C 2005 Role of tissue kallikrein in the cardioprotective effects of ischemic and pharmacological preconditioning in myocardial ischemia. FASEB Journal 19 1172-1174. (doi:10.1096/fj.04-3508fje)

Henriksen EJ, Jacob S, Kinnick TR, Youngblood EB, Schmit MB \& Dietze GJ 1999 ACE inhibition and glucose transport in insulin-resistant muscle: roles of bradykinin and nitric oxide. American Journal of Physiology $\mathbf{2 7 7}$ R332-R336.

Isami S, Kishikawa H, Araki E, Uehara M, Kaneko K, Shirotani T, Todaka M, Ura S, Motoyoshi S, Matsumoto K et al. 1996 Bradykinin enhances GLUT4 translocation through the increase of insulin receptor tyrosine kinase in primary adipocytes: evidence that bradykinin stimulates the insulin signalling pathway. Diabetologia 39 412-420. (doi:10.1007/ BF00400672)

Kakoki M, Sullivan KA, Backus C, Hayes JM, Oh SS, Hua K, Gasim AM, Tomita H, Grant R, Nossov SB et al. 2010 Lack of both bradykinin B1 and $\mathrm{B} 2$ receptors enhances nephropathy, neuropathy, and bone mineral loss in Akita diabetic mice. PNAS 107 10190-10195. (doi:10.1073/pnas.1005144107)

Kishi K, Muromoto N, Nakaya Y, Miyata I, Hagi A, Hayashi H \& Ebina Y 1998 Bradykinin directly triggers GLUT4 translocation via an insulinindependent pathway. Diabetes 47 550-558. (doi:10.2337/diabetes.47. 4.550)

Kohlman O Jr, Neves Fde A, Ginoza M, Tavares A, Cezaretti ML, Zanella MT, Ribeiro AB, Gavras I \& Gavras H 1995 Role of bradykinin in insulin sensitivity and blood pressure regulation during hyperinsulinemia. Hypertension 25 1003-1007. (doi:10.1161/01.HYP.25.5.1003)

Laatikainen T, Dunbar JA, Chapman A, Kilkkinen A, Vartiainen E, Heistaro S, Philpot B, Absetz P, Bunker S, O'Neil A et al. 2007 Prevention of type 2 diabetes by lifestyle intervention in an Australian primary health care setting: Greater Green Triangle (GGT) Diabetes Prevention Project. BMC Public Health 7 249. (doi:10.1186/1471-2458-7-249)

Levey AS, Bosch JP, Lewis JB, Greene T, Rogers N \& Roth D 1999 A more accurate method to estimate glomerular filtration rate from serum creatinine: a new prediction equation. Modification of Diet in Renal Disease Study Group. Annals of Internal Medicine 130 461-470. (doi:10.7326/0003-4819-130-6-199903160-00002)

Liu YH, Yang XP, Mehta D, Bulagannawar M, Scicli GM \& Carretero OA 2000 Role of kinins in chronic heart failure and in the therapeutic effect of ACE inhibitors in kininogen-deficient rats. American Journal of Physiology. Heart and Circulatory Physiology 278 H507-H514.

Mahajan H, Richards SM, Rattigan S \& Clark MG 2004 Local methacholine but not bradykinin potentiates insulin-mediated glucose uptake in muscle in vivo by augmenting capillary recruitment. Diabetologia 47 2226-2234. (doi:10.1007/s00125-004-1580-7)

Mather KJ, Steinberg HO \& Baron AD 2013 Insulin resistance in the vasculature. Journal of Clinical Investigation 123 1003-1004. (doi:10.1172/JCI67166)

Mayfield RK, Shimojo N \& Jaffa AA 1996 Skeletal muscle kallikrein. Potential role in metabolic regulation. Diabetes 45(Suppl 1) S20-S23. (doi:10.2337/diab.45.1.S20)

Meneton P, Bloch-Faure M, Hagege AA, Ruetten H, Huang W, Bergaya S, Ceiler D, Gehring D, Martins I, Salmon G et al. 2001 Cardiovascular abnormalities with normal blood pressure in tissue kallikrein-deficient mice. PNAS 98 2634-2639. (doi:10.1073/pnas.051619598)

Messadi-Laribi E, Griol-Charhbili V, Pizard A, Vincent MP, Heudes D, Meneton P, Alhenc-Gelas F \& Richer C 2007 Tissue kallikrein is involved in the cardioprotective effect of AT1-receptor blockade in acute myocardial ischemia. Journal of Pharmacological and Experimental Therapeutics 323 210-216. (doi:10.1124/jpet.107.124859) 
Mori MA, Araujo RC, Reis FC, Sgai DG, Fonseca RG, Barros CC, Merino VF, Passadore M, Barbosa AM, Ferrari B et al. 2008 Kinin $B_{1}$ receptor deficiency leads to leptin hypersensitivity and resistance to obesity. Diabetes 57 1491-1500. (doi:10.2337/db07-1508)

Mori MA, Sales VM, Motta FL, Fonseca RG, Alenina N, Guadagnini D, Schadock I, Silva ED, Torres HA, dos Santos EL et al. 2012 Kinin $\mathrm{B}_{1}$ receptor in adipocytes regulates glucose tolerance and predisposition to obesity. PLoS ONE 7 e44782. (doi:10.1371/journal.pone.0044782)

Nuutila P, Raitakari M, Laine H, Kirvela O, Takala T, Utriainen T, Makimattila S, Pitkanen OP, Ruotsalainen U, Iida H et al. 1996 Role of blood flow in regulating insulin-stimulated glucose uptake in humans. Studies using bradykinin, $\left[{ }^{15} \mathrm{O}\right]$ water, and $\left[{ }^{18} \mathrm{~F}\right]$ fluoro-deoxy-glucose and positron emission tomography. Journal of Clinical Investigation $\mathbf{9 7}$ 1741-1747. (doi:10.1172/JCI118601)

Ogden CL, Carroll MD, Kit BK \& Flegal KM 2012 Prevalence of obesity and trends in body mass index among US children and adolescents, 1999-2010. Journal of the American Medical Association 307 483-490. (doi:10.1001/jama.2012.40)

Rett K, Wicklmayr M, Dietze GJ \& Haring HU 1996 Insulin-induced glucose transporter (GLUT1 and GLUT4) translocation in cardiac muscle tissue is mimicked by bradykinin. Diabetes $\mathbf{4 5}$ (Suppl 1) S66-S69. (doi:10.2337/diab.45.1.S66)

Rothschild AM, Melo VL, Reis ML, Foss MC \& Gallo L Jr 1999 Kininogen and prekallikrein increases in the blood of streptozotocin-diabetic rats are normalized by insulin in vivo and in vitro. Naunyn-Schmiedeberg's Archives of Pharmacology 360 217-220. (doi:10.1007/s002109900068)

Sarzani R, Salvi F, Dessi-Fulgheri P \& Rappelli A 2008 Renin-angiotensin system, natriuretic peptides, obesity, metabolic syndrome, and hypertension: an integrated view in humans. Journal of Hypertension $\mathbf{2 6}$ 831-843. (doi:10.1097/HJH.0b013e3282f624a0)

Satterfield DW, Volansky M, Caspersen CJ, Engelgau MM, Bowman BA, Gregg EW, Geiss LS, Hosey GM, May J \& Vinicor F 2003 Communitybased lifestyle interventions to prevent type 2 diabetes. Diabetes Care 26 2643-2652. (doi:10.2337/diacare.26.9.2643)
Shiuchi T, Cui TX, Wu L, Nakagami H, Takeda-Matsubara Y, Iwai M \& Horiuchi M 2002 ACE inhibitor improves insulin resistance in diabetic mouse via bradykinin and NO. Hypertension 40 329-334. (doi:10.1161/ 01.HYP.0000028979.98877.0C)

Slim R, Torremocha F, Moreau T, Pizard A, Hunt SC, Vuagnat A, Williams GH, Gauthier F, Jeunemaitre X \& Alhenc-Gelas F 2002 Loss-of-function polymorphism of the human kallikrein gene with reduced urinary kallikrein activity. Journal of the American Society of Nephrology $\mathbf{1 3}$ 968-976.

Tschop M \& Heiman ML 2002 Overview of rodent models for obesity research. Current Protocols in Neuroscience Chapter 9 Unit 9.10.

Tschope C, Reinecke A, Seidl U, Yu M, Gavriluk V, Riester U, Gohlke P, Graf K, Bader M, Hilgenfeldt U et al. 1999 Functional, biochemical, and molecular investigations of renal kallikrein-kinin system in diabetic rats. American Journal of Physiology 277 H2333-H2340.

Waeckel L, Potier L, Chollet C, Taveau C, Bruneval P, Roussel R, AlhencGelas F \& Bouby N 2012 Antihypertensive role of tissue kallikrein in hyperaldosteronism in the mouse. Endocrinology 153 3886-3896. (doi:10.1210/en.2012-1225)

Williams TD, Chambers JB, Roberts LM, Henderson RP \& Overton JM 2003 Diet-induced obesity and cardiovascular regulation in $\mathrm{C} 57 \mathrm{BL} / 6 \mathrm{~J}$ mice. Clinical and Experimental Pharmacology \& Physiology 30 769-778. (doi:10.1046/j.1440-1681.2003.t01-1-03808.x)

Yuan G, Deng J, Wang T, Zhao C, Xu X, Wang P, Voltz JW, Edin ML, Xiao X, Chao L et al. 2007 Tissue kallikrein reverses insulin resistance and attenuates nephropathy in diabetic rats by activation of phosphatidylinositol 3-kinase/protein kinase B and adenosine 5'-monophosphate-activated protein kinase signaling pathways. Endocrinology 148 2016-2026. (doi:10.1210/en.2006-0602)

Zhu L, Carretero OA, Xu J, Wang L, Harding P, Rhaleb NE, Yang JJ, Sumners C \& Yang XP 2012 Angiotensin II type 2 receptor-stimulated activation of plasma prekallikrein and bradykinin release: role of SHP-1. American Journal of Physiology. Heart and Circulatory Physiology 302 H2553-H2559. (doi:10.1152/ajpheart.01157.2011)

Received in final form 9 January 2014

Accepted 5 February 2014

Accepted Preprint published online 5 March 2014
(C) 2014 Society for Endocrinology Printed in Great Britain
Published by Bioscientifica Ltd. 